\title{
Budgeting: A Strategic Managerial Tool
}

\author{
Elizabeth $M$. King \\ Wayne Norvell \\ Dan Deines \\ College of Business Administration \\ Kansas State University \\ Manhattan, Kansas
}

The industrial revolution in the United States greatly accelerated the need for human influence over future economic activity. Industrial development resulted in heavy industry accompanied by division of labor tasks and assembly line production. This complex development in our industrial society made budgetary procedures necessary for factory planning.

The first business budgets were adopted for the purpose of limiting expenditures ([13], p. 44). Many business managers began by budgeting expenses they considered discretionary, such as advertising, research, and capital expenditures. Recognizing that production scheduling and control also depended on detailed preparation, Frederick Taylor attempted to adapt current industrial operations by applying scientific management methods to questions of "task management" ([2], p. 195). Taylor believed that budgeting afforded a means of placing responsibility and measuring performance, rather than simply limiting expenditures. The budgeting task involved balancing needs and resources in order to reach specified objectives with a minimum expenditure.

Eventually, business budgeting went further in asserting that this was done best when annual and long-term plans were coordinated, and when goal-setting and program analysis were based on an ordered sequence of analytical steps. Budgeting, today, implies a two-step approach to events - (1) the planning process and (2) the control function. This paper examines the role of budgeting in the planning and control process and its importance as a strategic managerial tool. It extends the current literature by introducing the concept of a budget support schedule into the budgeting process.

\section{The Planning and Control Process}

Strategic planning and control is a process of deciding on corporate objectives, on the resources to be used, on the policies to control the procurement and use of those resources, and on the means (strategies) of attaining those objectives ([5], p. 11). As illustrated in Figure 1, a planning and control system consists of (1) formulating the

Journal of Business Strategies, Volume 5, Number 2 (Fall 1988) 
corporate objectives from which the (2) master plans (overall plans for implementing the corporate strategy) are developed. The business organization's strategic information system then provides (3) feedback on whether the strategy is being implemented as planned, and whether the strategy is yielding the desired results. After (4) comparing actual conditions with planned conditions, the controlling process (5) analyzes the differences and makes necessary changes.

\section{Figure 1}

\section{Model of Planning and Control Process}

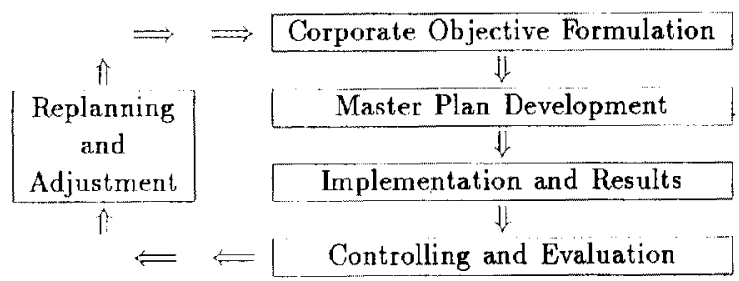

In making the strategir decisions that are foremost for strategic management and planning activities, three types of analysis are necessary:

1. Values Analysis - an assessment of the values, interests, desires, and expectations of the groups most affected by organizational plans.

2. Environmental Analysis - an cvaluation of the current and future state of the general environment (economic, technological, societal, legal, and political) with the industrial environment (competition, market structure and concentration).

3. Resource Analysis - an analysis of the level and quality of the personnel, technological, physical, and financial resources the organization can commit to the implementation of a strategy.

The role of budgeting, as a strategic managerial tool, lies with resource analysis. It is crucial for management to know what resources must be committed to corporate objectives.

\section{The Importance of Budgeting to Planning and Control}

A budget is a formalized, financial plan setting forth management's intended actions and the anticipated effects those actions will have on key business variables such as sales, production, expenses, and cash flows ([6], p. 926). The two major functions of a budget are planning and control.

First, budgeting requires the formulation of a thorough plan of operations for the budget period - hence its name, "profit planning." In constructing the budget, management must obtain and analyze data relating to such aspects of future operations as 
the prices, quantities, types, and availability of sources of financing [8]. The planning process begins with the establishment of the organization's goals, and budget planning must be in harmony with the long-run goals of the company as well as the short-run objectives such as target amounts of costs and income. Organizational goals state the desired position of the firm in the future. Since they are directional and motivational in nature, goals involve a continual process of change throughout time [1]. Without planming, most complex organizational ventures could be prone to crisis. However, budget planning provides management with a view of the future that serves as an early warning system for those contemplated actions that might lead to unacceptable results. A comprehensively prepared budget that shows how planned activities can lead to an acceptable net income indicates that management has done what it should to pian, successíul operations within its personnel, technological, physical, and financial irameworks.

Second, a budget may serve as a control. It contains criteria of cost performance which can be compared with actual data on operations, thus facilitating evaluations and enforcing some measure of efficiency. Frequent comparisons of budgeted and actual operating data are beileved to be sound operating procedures, and give cause for the application of "management by exception" principles which suggest that as long as operations conform with the budget, the activity is in control and no intervention is required $[10]$.

How are comprehensive budget planning and control related to the strategic functions of management? The response requires consideration of the basic functions of management and the nature of the management process. Fayol, a scholar and observer of the management process, stated that all activities of an industrial undertaking could be divided into six groups:

1. technical (production)

2. commercial (buying, selling, and exchange)

3. financial (search for, and use of capital)

4. security (protection of property and persons)

5. accounting (including statistics)

6. managerial (planning, organization, command, control, and coordination) [7].

Budget planning and control rests upon the conviction that management can plan and control the long-range destiny of the organization by making a continual stream of well-conceived decisions. The managerial decisions must be both purposive and futuristic [14]. By "purposive," it is meant that the stream of important managerial decisions must be primarily concerned with developing purpose in goals, and with devising realistic strategies to attain those goals. By "futuristic," it is meant that the important managerial decisions be fundamentally concerned with the long-range 
future as opposed to "spur-of-the-moment" decisions. The need for continuous interchange of plans, policies, and ideas, as well as for changes affecting them, is essential for demonstrating the implicit managerial self-confidence the firm must possess to achieve its goals. A budget, since it emphasizes goal congruence through realistic planning, dynamic control, and effective communication, establishes the basis for the harmony and unity needed for achieving managerial goals $([6]$, p. 926).

\section{Budget Preparation}

Even though specific budgeting procedures vary widely among organizations, all business enterprises which are engaged in comprehensive budgeting efforts must consider the organization's budget committee and the master budget.

An organization's budget committee generally consists of representatives from all major areas of the organization, such as sales, production, marketing, and finance, and is headed by the organization's controller. The committee is responsible for coordinating the preparation of the budget, initiating budget procedures, collecting and integrating data from various organizational units, supervising the review and modification of original estimates, and directing the implementation of the budget. When all organizational departments participate in formulating the budget, it is more likely to be accepled as a reasonable standard of performance [9].

The master budget is a comprehensive planning document that integrates all of the details for the various specialized activities of the firm [4]. It outlines the organization's plans for its operations and resources during a given period of time. It contains the data necessary to formulate projected financial statements for the budget period. The master budget is usually prepared in four parts: (1) the profit plan for operations, (2) the cash budget, (3) the projected statement of financial position, and (4) the capital expenditures budget ([3], p. 487). Supporting schedules for operational and resource budgeting are highly recommended, and should present cost data in great detail, taking into account all dimensions of an organization's plan. Budget support schedules are most effective if prepared by functional area: marketing, finance, production, etc. Preparation in this manner will provide qualitative and quantitative support for a comprehensive planning document.

Figure 2 presents a model of a budget support schedule for the marketing function. Note how the operations section identifies the overall goals of the division using both written descriptions of the goals and the dollar amounts expected to accomplish these goals. The resources section is a breakdown of the overall cost projections with written justification for each expenditure.

\section{Importance As A Strategic Managerial Tool}

The use of budgets for cost control and the evaluation of performance entails the preparation of periodic performance reports to measure effectiveness. Such reports compare budgeted and actual data and show any existing variances. It is critical in today's highly competitive market to not only discover variances, but also to make adjustments that reduce waste and improve competitive ability. 
Figure 2

Model of Budget Support Schedule

\section{Support Schedule for Marketing Budget}

Budget for: 19 to 19

Description of Budgeting Activity:

I. Operations

A. Marketing Objectives

B. Gross Revenue Objectives

C. Cost Projections (Quantitative Response) \begin{tabular}{l|l|l} 
1. Promotion & 2. Distribution & 3. Product
\end{tabular}

II. Resources

\begin{tabular}{|l|l|l|}
\hline Classification & Expenses & Purpose of Expenditure \\
\hline $\begin{array}{l}\text { - Media } \\
\text { - Advert. }\end{array}$ & & \\
- Per. sell. & & \\
\hline 2. & & \\
Distribution & & \\
& - Warehouse \\
- Transport. & & \\
- Inv. Control & & \\
Product & & \\
- Development & & \\
- Packaging & & \\
- Pricing & & \\
\hline
\end{tabular}


Activity or workload measures are very commonly found in current program and períoruance budgets. An example would be 'number of sales calls made' or 'number of employees in a training program.'

End result measures attempt to estimate outcomes that are as ultimate as possible. These measures can be expressed in any units that are appropriate.

In order for the effectiveness of an activity level, workload level, or end result to be measured, a means of setting and assessing the appropriate criteria must be set. In the development and use of appropriate effectiveness measures the accounting function is of major significance. At the center of the goal process is the commitment of resources; at the center of the resource allocation process is the budget; and at the center of the budget is the accounting activity. Goal development, resource allocation, budgeting, effectiveness measurement, and review of actual performance are all interdependent processes, each interacting with the other within the organizational environment ([11], p. 316).

\section{Summary and Conclusions}

Budgeting is a strategic managerial tool. As an integral component of the manageInent process, budgeting offers an approach for managing future performance consistent with specified management responsibilities. The budget imposes a self-discipline on management - to specify plans, to evaluate precisely their probable effects on the resource flows of the firm, and to measure and evaluate performance critically on a continuing basis.

From an organizational viewpoint, the budget affords a means through which management can agree on a planned allocation of resources that will facilitate the achievement of organizational goals. In today's highly competitive market, effective budgeting is more critical than ever before as a strategic managerial tool. This is true for firms of all sizes, from the smallest to the largest. Often, small entrepreneurs lack budgeting capabilities or awareness. This unfortunately has contributed to far too many companies failing to reach their potential or failing completely. For example, a company with a weak budgeting process may not anticipate a working capital shortfall and be faced with a liquidity crisis that could end its existence. There is certainly a need for the diffusion of the latest budgeting technology throughout the business world.

\section{References}

1. Caplan, Edwin H. "Behavioral Assumptions of Management Accounting." The Accounting Review, Vol. 41 (July, 1966), pp. 496-509.

2. Chatfield, Michael. A History of Accounting Thought. Huntington, NY: Robert E. Krieger Publishing Co. (1977).

3. DeCoster, Don T. and Eldon L. Schafer. Management Accounting: A Decision Emphasis. New York, NY: John Wiley \& Sons, Inc. (1982). 
4. Deverall, C. S. Management Planning and Control. London: Gee \& Co. (Publishers) Limited. (1967).

5. Digman, Lester. Strategic Management. Plano, TX: Business Publication, Inc. (1986).

6. Dittrich, Norman E., Ernest I. Hanson, and Paul H. Walgenbach. Principles of Accounting, second edition. New York, NY: Harcourt Brace Jovanovich, Inc. (1980).

7. Fayol, H. General and Industrial Administration. London: Sir Issac Pitman \& Sons, Ltd. (1949).

8. Finch, Gerald L. "Improving the Bottorn Line." Management Accounting, Vol. 69 (October, 1987), pp. 42-47.

9. Jones, John W. and Michael A. Wright. "Material Burdening." Management Accounting, Vol. 69 (August, 1987), pp. 27-31.

10. Lewin, Arie Y. and Michael Schiff. "Where Traditional Budgeting Fails." Financial Executive, pp. 51-58 (May 1968).

11. Livingstone, J. Leslie. "Organization Goals and the Budget Process." Abacus, Vol. 11 (June, 1975), pp. 306-17.

12. Novick, David. Origin and History of Business Budgeting. Santa Monica, CA: Rand Publishing (1966).

13. Theiss, Edwin L. "The Beginnings of Budgeting." The Accounting Review, Vol. 12 (January, 1937), p. 44.

14. Welsch, Glenn A. Budgeting: Profit Planning and Control. Englewood Cliffs, N.J.: Prentice-Hall, Inc. (1976). 